\title{
Promises of Apoptosis-Inducing Peptides in Cancer Therapeutics
}

\author{
David Barras and Christian Widmann*
}

Department of Physiology, Lausanne University, 1005 Lausanne, Switzerland

\begin{abstract}
Until recently, most research efforts aimed at developing anti-cancer tools were focusing on small molecules. Alternative compounds are now being increasingly assessed for their potential anti-cancer properties, including peptides and their derivatives. One earlier limitation to the use of peptides was their limited capacity to cross membranes but this limitation was alleviated with the characterization of cell-permeable sequences. Additionally, means are designed to target peptides to malignant cells. Most anti-cancer peptidic compounds induce apoptosis of tumor cells by modulating the activity of Bcl-2 family members that control the release of death factors from the mitochondria or by inhibiting negative regulators of caspases, the proteases that mediate the apoptotic response in cells. Some of these peptides have been shown to inhibit the growth of tumors in mouse models. Hopefully, pro-apoptotic anti-tumor peptides will soon be tested for their efficacy in patients with cancers.
\end{abstract}

Keywords: Apoptosis, Bcl-2, cancer, cell-permeable peptides, IAPs, peptides, RasGAP, Smac.

\section{INTRODUCTION}

In industrialized countries in general and in North America in particular, cancer is the second most important cause of death after heart diseases [1]. Although an important decrease was recorded in cancer death rates between 1990 and 2005 (19.2\% for men and $11.4 \%$ for women) in the United States, there are still about 1.5 million new cases of cancer estimated to occur in this country each year [1]. There is the need therefore to develop more efficient and selective cures to fight cancer. This will necessitate a further increase in our understanding of the mechanisms of cancer progression and the translation of this knowledge into the development of more efficient and specific anti-cancer drugs.

The characteristic features of a cancer cell have been classified by Hanahan and Weinberg into six categories: selfsufficiency in growth factor, as well as insensitivity to antigrowth signals, limitless replicative potential, capacity to metastasize and to sustain angiogenesis, and resistance to apoptosis [2]. A switch to aerobic glycolysis (the Warburg effect) is also recognized as the seventh hallmark by some [3-5]. All of these characteristic features of tumor cells can potentially represent targets for the development of anticancer drugs. In terms of ultimate efficiency, induction of apoptosis in tumor cells might represent the ideal anti-tumor therapy as no problematic cells are left behind.

A perfect anti-cancer drug has to kill cancer cells specifically, sparing non-transformed cells. Fortunately, the metabolic and cellular changes induced in tumor cells can be targeted to provoke their demise. Strategies exploring the possibilities to restore an appropriate apoptotic response in cancer cells, or even better, to tip the balance in favor of proapoptotic signals in these cells, are of great clinical interest. In this context, the use of therapeutic peptides as an alterna-

*Address correspondence to this author at the Department of Physiology, Rue du Bugnon 7/9, 1005 Lausanne, Switzerland, Tel: +41 21692 5123; Fax:+41 21692 5505; E-mail: Christian.Widmann@unil.ch tive to small molecule drugs has become an increasingly promising strategy to induce cancer cell apoptosis in a specific and targeted manner. Peptides are of low molecular weight and generally display low toxicity and high bioavailability. In addition, by fusing them to cell-penetrating moieties, therapeutic peptides can display improved targetable and deliverable properties. Finally, they can be produced easily and at low cost. All these advantages have made the anti-cancer peptide research field very active lately as reported in a number of interesting recent reviews [6-12].

The present review will focus on therapeutic anti-cancer peptides targeting the apoptosis signaling pathway. There will be a brief description of the molecular mechanisms controlling apoptosis, followed by a short section on recent improvements in peptide cell delivery. The main part of the review will however be devoted to the discussion of specific anti-tumor therapeutic peptides (the characteristics of which are described in Table 1). Work performed with protein sequences that have anti-cancer properties but that do not involve synthetic peptides (e.g. ADD70 derived from AIF [13]) will not be touched upon here.

\section{Apoptosis}

Apoptosis, or programmed cell death, is a physiological cell suicide program that is essential for the development and maintenance of healthy tissues [14]. Apoptosis is generally impaired during carcinogenesis, thereby preventing damaged cells to die $[15,16]$. However, it has to be noted that it is actually the balance between the rate of proliferation and the rate of death that determines tumor growth. There are cases of cancers displaying an increased apoptosis rate but where the population of cancer cells still increases due to overwhelming proliferation [17]. Nevertheless, as defect in apoptosis often plays a major role in cancer generation, rescuing and inducing apoptosis to get rid of these potential dangerous cells arose as an attractive anti-cancer approach [16]. 
Table 1. Characteristics of Pro-Apoptotic Peptides. This Table Displays the Nature and some of the Properties of the Peptides Described in this Review

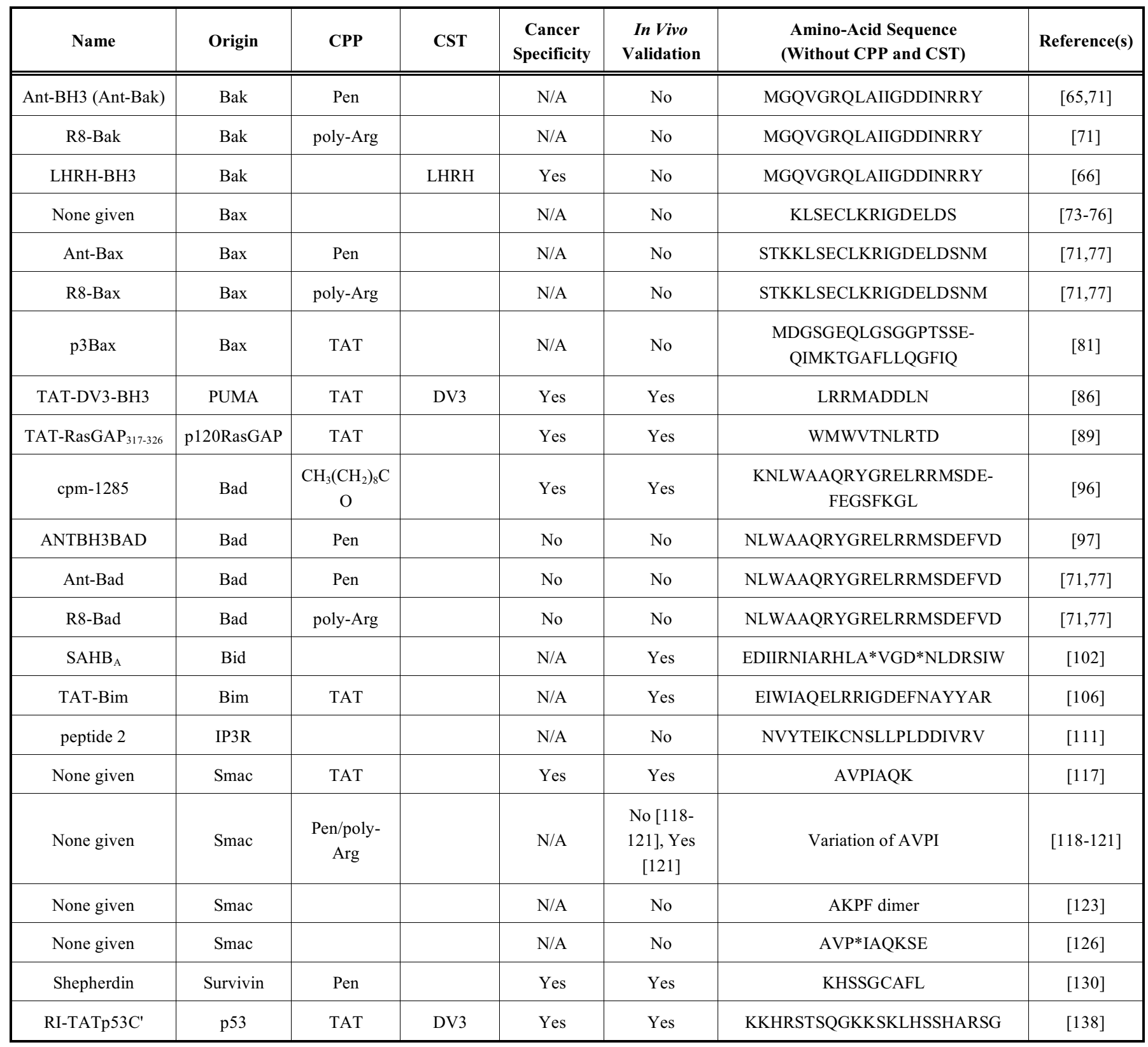

Abbreviations not Mentioned in the Text: CST, Cancer-Specific Targeting; DV3, DV3 Domain of the CXC Chemokine Receptor-4; LHRH, Luteinizing Hormone Releasing Hormone; Pen, Penetratin; N/A, not Analyzed. Asterisks Denote chemically Modified Amino-Acids.

Apoptosis is well characterized biochemically and morphologically [14]. Cells undergoing apoptosis shrink, cleave their DNA, fragment their nucleus and organelles, and are partitioned into apoptotic bodies, ensuring their efficient elimination by professional phagocytes or neighboring cells [18-21]. All the characteristic features of apoptosis are induced following the cleavage of substrates of proteases of the caspase family [14]. Caspases involved in apoptosis belong to either the upstream initiator caspases or the downstream effector caspases [22]. The effector caspases, caspase- $3,-6$, and -7 , are activated by cleavage mediated by the initiator caspases $(-8,-9$, and -10$)$. Whether caspase- 2 is an upstream downstream caspase is still debated [23]. There are two main cellular pathways involved in caspase activation (Fig. 1). The intrinsic pathway involves the release of cytochrome-c from mitochondria, leading to formation of a multi-protein platform called the apoptosome that results in the activation of caspase-9. The apoptosome is formed when the scaffold protein APAF-1, following its binding to cytochrome-c, oligomerizes. The complex then recruits caspase-9 that becomes activated [24]. Mitochondrial release of cytochrome-c is mediated by Bax and Bak, the activity of which is controlled by the balance of pro- versus anti-apoptotic members of the Bcl-2 family [25]. The extrinsic pathway, on the other hand, relies on the stimulation of death receptors that activate caspase- 8 and -10 [14]. The extrinsic pathway 


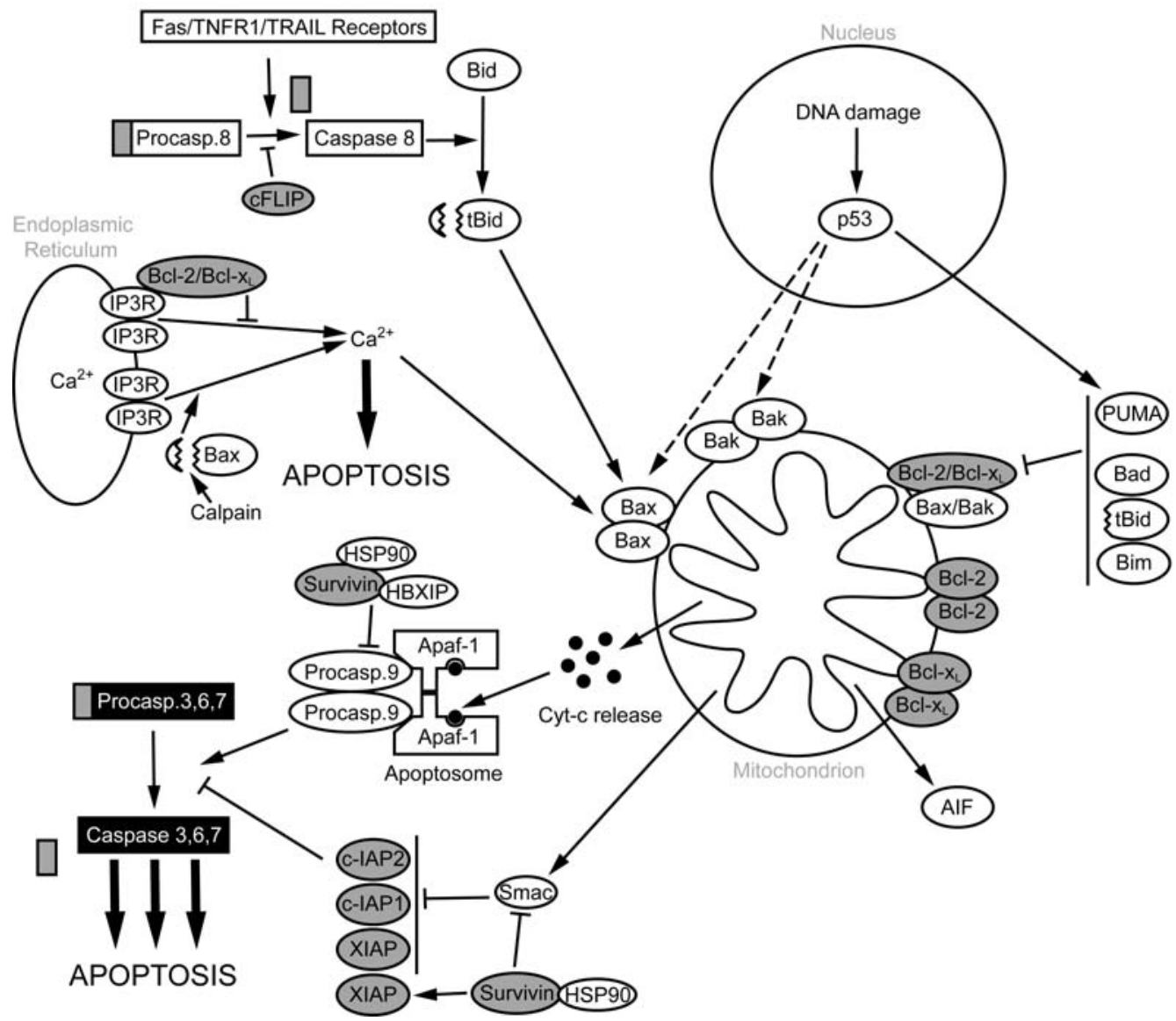

Fig. (1). Apoptotic signaling pathways. The intrinsic and extrinsic pathways are schematized. The main players involved in apoptotic signaling are indicated (see text for details). The anti-apoptotic proteins are grey-colored, while the pro-apoptotic ones are not.

has the possibility to cross-talk with the intrinsic pathway by inducing the cleavage of Bid, a BH3-only Bcl-2 family member [14] (see below). There are additional apoptosis regulatory proteins, including the inhibitors of apoptosis proteins (IAP) family [26,27] and proteins like Smac/DIABLO that is released from mitochondria together with cytochrome$\mathrm{c}$ and that prevents IAPs from inhibiting caspases [28].

In pre-malignant cells, apoptosis can be triggered by DNA damages resulting from oncogene activation [29]. Death receptor ligands can also stimulate tumor cell apoptosis, and some of these (e.g. TRAIL) appear to selectively target cancer cells and leave normal cells unaffected [30]. As indicated above, cancer progression often implies acquired resistance to this type of apoptosis and to cell death mediated by anti-cancer drugs [31]. Due to the variety of signals that lead to apoptosis, it is nevertheless still possible, at least in vitro, to induce death in cancer cells if the appropriate stimuli are used. However, these stimuli might not always be compatible with an in vivo usage due to toxicity to normal tissues. Restoration of apoptosis sensitivity in tumor cells can potentially be achieved by counteracting the action of the proteins that inhibit apoptosis and by favoring the activity of those that stimulate it. Several synthetic peptides have been shown to be able to do so.

\section{Therapeutic Peptide Design Improvement}

Many molecules displaying potent effects on tumor cells in vitro apparently fail to reach clinical trials because either of low delivery efficiency or low bioavailability and in vivo stability. A potent but non-deliverable drug is useless. A major concern in therapeutic development is therefore drug delivery. For these reasons, effort has been put into developing efficient delivery strategies including nano-particle-, polycationic- and lipid-based methods [11]. However, only a few of them have reached clinical trials [9].

Methods based on cell-penetrating peptides (CPPs) have promising potential in the context of drug delivery. They have emerged twenty years ago with the discovery of the ability of the HIV-1 TAT protein to enter cells $[32,33]$ and the characterization of the TAT sequence allowing this to occur [32, 34-36]. Since then, a variety of other CPPs were identified, often from natural proteins [37], including penetratin, a 16-mer-peptide derived from the Antennapedia homeodomain-containing protein of Drosophila melanogaster [38], VP-22, a protein from the herpes simplex virus type 1 [39], Pep-1, a synthetic peptide derived from the nuclear localization sequence of the SV40 large T antigen [40], polyarginine sequences [41], and many others (reviewed in [37]). Although the mode of cellular entry of CPPs still requires full characterization (reviewed in [37]), their utiliza- 
tion as cell permeable sequences has been largely adopted. Up to now, CPPs have been used as carriers for circular DNA, oligonucleotides, siRNA, liposomes, proteins, peptides [37] and even the anti-cancer drug doxorubicin [42]. CPPs can be used in vivo to deliver their cargo to virtually all tissues [43]. Methodologies based on CPPs are constantly being improved as demonstrated by the recent characterization of penetration accelerating sequences (PAS) that significantly increase the cytosolic release of CPPs taken up by cells [44].

One potential problem with peptides is rapid degradation in biological fluids. Peptide stability can be greatly ameliorated however if they are synthesized using D-amino acid enantiomers instead of the natural L-amino forms because Damino acid peptides cannot be easily recognized by proteases [45]. To best mimic the structure of the natural peptides, the sequence of the D-peptide is generally inverted, generating the so-called retro-inverso form [45].

Another arm of improvement in anti-cancer drug development concerns target specificity. Efforts are therefore made to specifically deliver these drugs to cancer cells. This could be achieved by taking advantage of the fact that tumor cells express proteins that are not present on normal cells (or at least not to the same levels). Drugs can be modified so as to contain structures allowing them to bind cancer-specific proteins or molecules. A list of the most cancer specific proteins has been published [46]. Some of these proteins could be targeted for the development of cancer homing devices. Examples include the chemokine receptor CXCR4, the luteinizing hormone releasing hormone receptor LHRHR and survivin. Another example is the GRP78/BiP endoplasmic reticulum chaperone that, in contrast to normal cells, is often expressed at the surface of cancer cells [47]. It has been shown that GRP78/BiP binding peptides linked to cytotoxic peptides specifically target and kill cancer cells in vivo [48], providing the proof-of-concept that cell surface GRP78/BiP can mediate tumor-specific internalization of cytotoxic compounds.

\section{PEPTIDES TARGETING MEMBERS OF THE APOP- TOSIS SIGNALING PATHWAY}

\section{Bcl-2 Family-Derived Peptides}

The Bcl-2 protein family is a major component in the apoptotic signaling pathway, and the improper regulation of some of its members is associated with drug resistance and malignant diseases [49]. Bcl-2 family proteins contribute to cell death via the mitochondrial pathway in response to DNA-damage, gamma-irradiation, growth factor deprivation, but also after activation of death receptors (e.g. Fas, TNF, TRAIL) and cross-talk with the mitochondrial intrinsic pathway $[50,51]$. Bcl-2-family members are divided in two categories bearing opposite activities in the regulation of apoptosis. Pro-apoptotic Bcl-2 family members are themselves subdivided in two additional groups, those harboring three Bcl-2 Homology (BH) domains, including Bax and $\mathrm{Bak}$, and those containing only the third $\mathrm{BH}$ domain, the socalled "BH3-only" proteins, including Bid, Bad and PUMA. Anti-apoptotic Bcl-2 family proteins, such as Bcl-2 and Bcl$\mathrm{X}_{\mathrm{L}}$, bear the same three $\mathrm{BH}$ domains (BH-1 to -3 ) as the proapoptotic ones but they also harbor a fourth domain (the
BH4 domain) implicated in their anti-apoptotic activity [52]. However, the mere presence of the BH4 domain does not necessarily make its bearer an anti-apoptotic protein as some pro-apoptotic Bcl-2- family members, such as Diva and Bcl$\mathrm{X}_{\mathrm{S}}$, do contain this domain $[53,54]$.

The balance of pro- and anti-apoptotic proteins tightly determines the fate of a cell and Bcl-2 family members play a major role in this regulation. In healthy cells, Bcl-2 and $\mathrm{Bcl}-\mathrm{X}_{\mathrm{L}}$ bind to Bak and Bax to block their ability to release cytochrome-c (Fig. 1). Upon apoptogenic stimuli, BH3-only proteins bind to anti-apoptotic Bcl-2 family members, leaving Bax and Bak free to be activated to form the cytochromec releasing structure in the mitochondrial membrane. The BH3-only proteins Bid and Bim are not only favoring cell death by titrating anti-apoptotic members. They may also directly activate Bax and Bak [55]. One model postulates in fact that inhibition of anti-apoptotic Bcl-2 family members is insufficient to cause apoptosis in the absence of direct Bax and Bak activation (i.e. by Bid or Bim) [56]. This model appears however incompatible with a number of observations, including data showing that $\mathrm{Bid}^{-/-} \mathrm{Bim}^{-/-}$fibroblasts remain sensitive to pro-apoptotic stimuli activating the intrinsic death pathway (reviewed in [57]). Recently, however, a NMR analysis has revealed a physical interaction site on Bax for a Bim-derived synthetic peptide located away from the hydrophobic BH3-binding pocket of Bax [58]. This newly identified site seems to account for the direct activating effect of Bim on Bax [58].

Bcl-2 family proteins are deregulated in most cancers and they play an important role in cancer chemo-resistance [59, $60]$. Very recently, Bcl-2 has also been shown to be involved in cell invasion and metastasis formation [61], making it an even more attractive target for cancer therapy. Bcl-2 and $\mathrm{Bcl}-\mathrm{X}_{\mathrm{L}}$ are often over-expressed in cancer cells. As a consequence, the activation of Bax and Bak is impaired, preventing cells from undergoing apoptosis. Thus, agents that are able to disrupt the interaction between pro- and antiapoptotic Bcl-2 proteins have attractive therapeutic potential. The conceptual goal in Bcl-2 family targeting is to mimic the pro-apoptotic proteins or to inhibit the anti-apoptotic ones. Since Bcl-2 family dimerization is mediated mainly by the BH3 domain, most efforts are devoted to synthesize small BH3-mimicking molecules or peptides that can inhibit antiapoptotic Bcl-2 family members. The laboratory of David Huang provided in 2005 a thorough analysis of the affinity of eight $\mathrm{BH} 3$ peptides for five Bcl-2-like proteins [62]. It was found that PUMA and Bim were the only BH3-only proteins able to engage all anti-apoptotic Bcl-2 family members. Other BH3-only proteins displayed a more limited spectrum of interactions. This information can be useful in defining the most appropriate $\mathrm{BH} 3$ peptides to be used to treat cancers over-expressing given pro-survival Bcl-2 family members.

\section{Bak-Derived Peptides}

Both Bak and Bax are proteins involved in formation of cytochrome-c releasing structures in the mitochondrial membrane [57]. In a healthy cell, Bak is anchored in the mitochondrial membrane, while Bax is mainly located in the cytoplasm. During the apoptosis process, both are localized and activated in the mitochondrion membrane, where they 
exert their permeation function. This leads to the release of cytochrome-c from the mitochondria, as well as other proapoptotic effectors including Smac, AIF, endonuclease G [63]. As indicated above, Bak and Bax are inhibited when they bind to Bcl-2 family members. Preventing such interactions is therefore an attractive way to prompt cancer cells to undergo apoptosis.

One of the first identified peptide targeting a Bcl-2 family member was described in 1997 by the laboratory of Stephen Fesik [64]. It corresponds to a 19 amino acid-long sequence derived from the $\mathrm{BH} 3$ domain of Bak that binds and negatively titrates out $\mathrm{Bcl}-\mathrm{X}_{\mathrm{L}}$ [65]. This peptide was used to determine the $3 \mathrm{D}$-structure of the interaction between $\mathrm{Bcl}-\mathrm{X}_{\mathrm{L}}$ and the death-promoting region of Bak [64]. When coupled to the penetratin CPP, this peptide, within 3-6 hours, induces cell death with the characteristic morphological features of apoptosis such as reduction in cell volume, nuclear condensation and membrane blebbing [64]. A mutant peptide unable to bind to $\mathrm{Bcl}-\mathrm{X}_{\mathrm{L}}$ does not induce apoptosis [64]. This indicates that inhibition of $\mathrm{Bcl}-\mathrm{X}_{\mathrm{L}}$, and possibly other antiapoptotic Bcl-2 family members, mediates the apoptotic response induced by the Bak-BH3 peptide.

A major concern in cancer therapy is to minimize the side effects of drugs on normal tissues. In this context, targeting drugs directly to cancer cells would be beneficial. Dharap et al. took advantage of the fact that luteinizing hormonereleasing hormone (LHRH) receptors are expressed at the surface of ovarian, breast and prostate cancer cells but not in most other visceral organs. They coupled a Bak-derived BH3 peptide to a decapeptide from LHRH and found that this hybrid peptide was able to kill specifically LHRH receptorexpressing cells [66]. Such an approach represents an elegant solution to deliver anti-cancer peptides to their targets and spare bystander cells. It has been shown indeed that the LHRH decapeptide allows the genotoxin drug camptothecin to induce a stronger and more specific anti-tumoral effect in vivo [67]. One can therefore predict that hybrid peptides composed of BH3 sequences and the LHRH decapeptide will also be more efficacious in whole organisms compared to peptides lacking the tumor-homing device.

Head and neck squamous cell carcinoma (HNSCC) can be treated by gamma radiation, EGF receptor inhibition, and chemotherapy after surgery [68], but unfortunately these treatments, if not fully efficacious, often select tumor cells with increased resistance to therapy [69]. These resistances can theoretically result from $\mathrm{Bcl}-2$ and $\mathrm{Bcl}-\mathrm{X}_{\mathrm{L}}$ overexpression that would prevent Bak and Bax activation [70]. Li et al. used a 19-mer Bak-derived peptide fused to penetratin or polyarginine CPPs in order to buffer the anti-apoptotic activity of Bcl-2 and Bcl- $\mathrm{X}_{\mathrm{L}}$ in three $\mathrm{HNSCC}$ cell lines and this led to efficient killing of the tumor cells [71].

\section{Bax-Derived Peptides}

An early study on the Bcl-2 family interactions [72] reported that mutations within the $\mathrm{BH} 1$ and $\mathrm{BH} 2$ domains of Bcl-2 abrogate the Bcl-2-Bax heterodimerization while not affecting the Bcl-2-Bcl-2 homodimerization, suggesting that Bcl-2 binding sites for Bax and Bcl-2 itself were not identical. Three years later however, evidence was presented that only one site was responsible for these bindings, including the description of a 15-mer Bax peptide (Bax amino acids 59-72) able to block Bcl-2 and Bcl- $\mathrm{X}_{\mathrm{L}}$ homodimerization and Bax binding to either Bcl-2 or Bcl- $\mathrm{X}_{\mathrm{L}}$ [73]. Regardless of whether the binding of Bax to Bcl-2 involves the same region necessary for $\mathrm{Bcl}-2$ dimerization, the identification of a Bax-derived peptide able to disrupt complexes between pro- and anti-apoptotic Bcl-2 family members opened the possibility to use it as a tool to promote cancer cell death. Bax (and Bak) BH3-derived peptides were indeed shown to induce cytochrome-c release from isolated mitochondria [74] indicating that disruption of pro- and anti-apoptotic Bcl-2 protein complexes leads to a functional activation of the intrinsic apoptotic pathway. The pro-apoptotic activity of Bax peptides was then shown on whole cells after electroporation [75], microinjection in cells [76], or using cell-permeable version of the peptide $[71,77]$. Induction of apoptosis by the Bax BH3 peptide appears to occur through disruption of the pro-and anti-apoptotic Bcl-2 protein complexes rather than by direct activation of Bak and Bax as the peptide is neither able to induce Bax translocation to the mitochondria nor to stimulate the apoptotic activity of a recombinant form of Bax [78].

Calpain is a calcium-dependant protease that can cleave Bax into a $18 \mathrm{kDa}$ fragment (p18Bax) and a 32 amino acid peptide (p3Bax) [79] (Fig. 1). The consequence of this cleavage is that it generates a more active version of Bax ( $\mathrm{p} 18 \mathrm{Bax}$ ) [80]. The function of $\mathrm{p} 3 \mathrm{Bax}$ is less well understood. A cell-permeable version of p3Bax (TAT-p3Bax) slightly enhances apoptosis in response to the Sarco/ Endoplasmic Reticulum $\mathrm{Ca}^{2+}$-ATPase (SERCA) inhibitor thapsigargin by increasing the release of calcium into the cytoplasm. Although it has been suggested that this release involves the inositol 1,4,5-triphosphate receptor (IP3R), the underlying mechanisms remain at the moment elusive [81]. TAT-p3Bax alone does however not affect cell survival. Prostate and colon cancer cells display increased expression of transient receptor potential cation channel subfamily $\mathrm{M}$ member 8 (TRPM8), a plasma membrane $\mathrm{Ca}^{2+}$ channel, and decreased SERCA3 levels, respectively (reviewed in [82]). This would favor elevation in cytosolic $\mathrm{Ca}^{2+}$. If TAT-p3Bax favors apoptosis in cells with increased cytosolic calcium concentrations it could then potentially be efficacious in treating these cancers.

\section{PUMA-Derived Peptides or Peptides Favoring the Activity of PUMA}

p53-upregulated modulator of apoptosis (PUMA) is a pro-apoptotic BH3-only protein, the expression of which, as its name implies, is controlled by p53 [83]. It binds and inhibits all known anti-apoptotic Bcl-2-family members [62] and may be able, although this is debated, to directly activate Bax and Bak [57]. PUMA mediates apoptosis of cells in response to stresses such as DNA damage that lead to p53 activation but also in response to p53-independent apoptotic stimuli (e.g. staurosporine) [84, 85].

It has recently been reported that a cell-permeable PUMA-derived peptide can trigger apoptosis in a broad panel of cancer cell lines, but not normal cells [86]. This peptide is composed of a 9 amino acid sequence found in the BH3 domain of PUMA (LRRMADDLN) that has the capac- 
ity to dissociate $\mathrm{Bcl}-\mathrm{X}_{\mathrm{L}}$ from $\mathrm{Bax}$ [87]. It also contains the sequence encoding the CXC chemokine receptor-4 (CXCR4) ligand allowing it to bind to this receptor. As many tumors from different origins over-express this receptor [88], this might allow preferential targeting of the PUMA-containing pro-apoptotic peptide to its intended target. Consistent with this prediction is the observation that injection of this peptide in the tail vein preferentially accumulated in tumors in mice [86]. Future in vivo investigations will tell whether this enhanced targeting to tumors correlates with a better anti-tumor activity compared to peptides lacking the CXCR4 receptor ligand sequences.

Our laboratory has characterized a peptide that is not derived from a Bcl-2 family member but that nevertheless impinges on the p53-PUMA pathway to favor the death of cancer cells. This peptide is derived from a caspase-3generated fragment of the RasGAP protein, called fragment $\mathrm{N} 2$, that specifically sensitizes tumor cells to genotoxininduced apoptosis [89]. Fragment N2 renders tumor cells such as HeLa, U2OS, and HCT116 cells exquisitely sensitive to the killing action of various genotoxins (cisplatin, adriamycin, mitoxantrone, etc) [90, 91]. The genotoxinsensitizing activity of fragment $\mathrm{N} 2$ has been narrowed down to a 10 amino acid long sequence [89]. TAT-RasGAP ${ }_{317-326}$, a synthetic, cell-permeable peptide bearing this sequence, increases the ability of genotoxins to induce apoptosis in tumor cells [89]. Recently, a more stable version of the peptide, made of D-amino acids, has been demonstrated to increase the efficacy of genotoxins in several tumor mouse models [92]. This peptide only functions in cells expressing a functional $\mathrm{p} 53$ protein and its genotoxin-sensitization activity requires PUMA [93]. As TAT-RasGAP ${ }_{317-326}$ does not modulate the activity of p53 or the levels of PUMA, our current working hypothesis is that it increases the activity of PUMA, consistent with the observation that the extent of mitochondrial potential decrease induced by cisplatin is augmented in presence of the peptide [93].

\section{Bad-Derived Peptides}

$\mathrm{Bad}$ is another BH3-only protein that binds to Bcl-2, Bcl$\mathrm{X}_{\mathrm{L}}$, and Bcl-w $[62,94]$. There are indications that the $\mathrm{Bad}$ BH3 domain has higher binding affinities for $B c 1-X_{L}$ than BH3 domains from other Bcl-2 family members [95]. Badderived peptides may therefore represent particularly potent anti-cancer tools to treat cancer cells with increased expression of $\mathrm{Bcl}-\mathrm{X}_{\mathrm{L}}$. The first design of a cell-permeable Badderived peptide to treat tumor cells was reported in 2000 [96]. This peptide, called cell permeable moiety (cpm)- 1285 corresponds to a 24 amino acid-long sequence derived from the Bad BH3 domain (amino acid 142-165) coupled to a decanoid fatty acid $\left[\mathrm{CH}_{3}\left(\mathrm{CH}_{2}\right)_{8} \mathrm{CO}\right]$ to render it cell permeable. Cpm-1285 binds strongly to Bcl-2 with an $\mathrm{IC}_{50}$ of 130 $\mathrm{nM}$, while a mutated peptide, in which the $\mathrm{Bad} \mathrm{BH} 3$ leucine 151 is mutated into an alanine, has 15 times increased $\mathrm{IC}_{50}$. Cpm-1285 was shown to induce apoptosis of HL-60 cells, a human myeloid leukemia cell line. The caspase inhibitor zVAD-fmk could block this response, strengthening the notion that the peptide was mediating its effects through caspase activation. A non-cancerous peripheral blood lymphocyte (PBL) cell line was not affected by the presence of the peptide, emphasizing its cancer specificity. SCID mice injected with HL-60 tumor cells subsequently treated with the mutant peptide or left untreated survived approximately 11-12 days, while mice treated with cpm-1285 had their lifespan extended by 27 days. This promising leukaemia therapy strategy now needs to be translated to human.

One year later, in 2001, another Bad peptide (amino acid 103 to 123), encoding the $\alpha$-helical structure of the BH3 domain, was coupled to the penetratin CPP and tested for its ability to kill cells [97]. This peptide, called ANTBH3BAD, efficiently interacted with Bcl-2. Surprisingly however, it induced apoptosis in a Bcl-2-independent manner and it was found that its toxicity was actually due to its alpha helicity. Alpha-helical structures when amphipathic and when bearing cationic residues are known to break the positively charged membrane of bacteria, but not those of mammalian cells that are neutrally charged and stabilized by cholesterol $[98,99]$. When such peptides are internalized into mammalian cells however, they are able to disrupt the negatively charged mitochondrial membrane and this leads to the activation of the apoptotic intrinsic pathway [100]. Thus, the ANTBH3BAD peptide appears to induce cell death like cationic amphipathic helices and will therefore not be able to discriminate between normal and cancer cells, unless modified in such a way as to specifically target the latter.

Since interaction of Bcl-2 family members is mediated by their $\mathrm{BH} 3$ domains, the specificity and strength of these interactions are important parameters to gather in order to define which $\mathrm{BH} 3$ peptide-based strategies have to be elected according to the $\mathrm{Bcl}-2$ protein expression profile of the cancers to be treated. A study published in 2002 provided some information in this context [101]. Comparison of the efficacy of BH3 peptides derived from Bax, Bad and Bcl-2 for their ability to disrupt $\mathrm{Bax} / \mathrm{Bcl}-2$ and $\mathrm{Bax} / \mathrm{Bcl}-\mathrm{X}_{\mathrm{L}}$ heterodimers and $\mathrm{Bax}$ or $\mathrm{Bcl}-2$ homodimers indicated that the Bax peptide is more potent in dissociating Bax/Bcl-2 complexes, while the Bad peptide is more efficacious in disrupting $\mathrm{Bax} / \mathrm{Bcl}-\mathrm{X}_{\mathrm{L}}$ complexes. These in vitro results suggest that Bax peptides should be used to treat cancer overexpressing Bcl-2, while Bad peptides should be chosen to treat those that over-express Bcl- $\mathrm{X}_{\mathrm{L}}$. However, care must be taken here because works with cancer cells do not always confirm such assumption (see [71] for example). Obviously, the situation with living cells is more complex and additional cell death regulators will determine the eventual efficacy of a given $\mathrm{BH} 3$-derived peptide on tumors.

\section{Bid-Derived Peptide}

Bid is a peculiar BH3-only protein because it can link the extrinsic and the intrinsic pathways when it is cleaved by caspase-8 [14]. It mediates its pro-apoptotic activity by interacting with the anti-apoptotic Bcl-2 members and maybe also by directly activating Bax and Bak [55]. The group of Stanley Korsmeyer modified BH3 $\alpha$-helical structures using a method termed hydrocarbon stapling that consists in replacing the amino-acids on one side of the helix with nonnatural chemically modified amino-acid that covalently interact, thereby stabilizing the helix chemical structure and increasing its in vivo activity. The resulting peptides were called "stabilized $\alpha$-helix of Bcl-2 domains" (or SAHBs) [102]. A SAHB of the BH3 domain from the Bid protein 
(amino acid 80 to 101) displayed stronger apoptotic-inducing activities compared to the non-modified Bid peptide. Additionally, the Bid SAHB effectively inhibited the growth of human leukemia xenografts in mice. SAHBs therefore represent potentially useful tools to treat cancer with deregulated Bcl-2 proteins.

\section{Bim-Derived Peptides}

Bim is a BH3-only Bcl-2 family member, the activity of which is controlled through its interaction with microtubule structures. Bim is inactive when bound to microtubuleassociated dynein motor complexes but its release from it, in response to microtubule perturbing drugs for example, allows it to inhibit anti-apoptotic Bcl-2 proteins, favoring therefore apoptosis. Bim, and another BH3-only member called Bmf that interacts with actin structures, allow therefore cells to engage an apoptotic program when their cytoskeleton is damaged. Bim can also be regulated by ERKmediated phosphorylation [25]. As indicated above, Bim, like PUMA, has the capacity to titrate all pro-survival Bcl-2 proteins and consequently use of Bim mimetics can potentially have great efficacy in killing cancer cells.

As can be expected from its mode of activation, Bim plays an important role in taxane-induced cancer cell apoptosis. Taxanes (e.g. taxol, paclitaxel) stabilize microtubules, in particular those of the spindle apparatus, and this induces cell cycle arrest at the G2/M stage, spindle check-point activation, and subsequently apoptosis [103]. Taxanes are effective chemotherapeutic agents against cancers originating from lung, prostate and breast. The susceptibility of cancer cells to taxane-induced apoptosis has been shown to depend on the levels of Bim expression [104]. Taxanes might not only liberate pools of Bim initially associated with microtubule structures, they also appear to induce de novo expression of Bim [104,105], via Foxo3a-mediated transcription [105].

A peptide containing the cell permeable TAT moiety and sequences from the $\mathrm{BH} 3$ domain of Bim has been used to successfully kill various cancer cells in vitro [106]. Intratumoral injection of this peptide was also able to slow down the growth of a pancreas adenocarcinoma tumor implanted in syngeneic mice and to increase the survival of these animals [106]. It will now be interesting to see if stabilized version of Bim peptides, such as those used in the characterization of the Bim binding site on Bax [58], are efficacious in vivo antitumor agents. It has to be kept in mind however that Bim is able to inhibit all pro-survival Bcl-2 proteins and this might lead to unacceptable side-effects on normal tissues.

\section{Bcl-2 and Bcl-X $X_{L}$ BH4-Based Peptides}

The anti-apoptotic $\mathrm{Bcl}-2$ and $\mathrm{Bcl}-\mathrm{X}_{\mathrm{L}}$ proteins are upregulated in several common human malignancies, including prostate, colon, breast, small cell lung cancer, and follicular B-cell lymphoma, and this correlates with poor prognosis and chemotherapy resistance $[50,107]$. Since $\mathrm{BH} 4$, a domain borne by both Bcl-2 and Bcl- $\mathrm{X}_{\mathrm{L}}$, is essential for their antiapoptotic effect on pro-apoptotic Bcl-2 family members [108], it is of particular interest for drug designers.

Another interesting aspect of the BH4 domain is that it appears to negatively regulate calcium-dependent apoptosis.
The BH4 domain interacts with the IP3R, inhibiting the IP3mediated $\mathrm{Ca}^{2+}$ release from the endoplasmic reticulum to the cytoplasm and, this consequently can prevent $\mathrm{Ca}^{2+}$-induced apoptosis [52, 109]. A peptide-based approach preventing the BH4-IP3R interaction has been designed to prevent this inhibitory action of the BH4 domain (reviewed in [110]). The laboratory of Clark Distelhorst identified a 20 amino acids sequence within the IP3R, which they called "peptide 2", that was shown to mediate the binding of the IP3R to the Bcl-2 BH4 domain [111]. As expected, this peptide was able to abrogate the IP3R-Bcl-2 interaction, thereby reversing the Bcl-2 inhibitory effect on IP3R channel opening. The anticancer activity of this peptide has yet to be evaluated.

\section{IAPs and Smac-Derived Peptides}

A cell that needs to survive has to tightly control its caspase activity. Inhibitors of apoptosis proteins (IAPs) represent one family of proteins that can be used by cells to achieve this regulation. IAPs inhibit caspases either directly by binding to them or indirectly by promoting their degradation [112]. The best described IAP members are XIAP, cIAP1, c-IAP2, and survivin. IAP over-expression, survivin in particular, is one of the reasons cancer cells develop resistance against chemotherapy [26]. IAP family members share four domains: the baculoviral IAP repeat (BIR) domain, the caspase recruitment domain (CARD), the really interesting new gene (RING) and the ubiquitin-conjugated (UBC) domains. IAPs can contain up to three BIR tandem repeats, called BIR1, BIR2, and BIR3. Only CARD and BIR domains are involved in the inhibition of caspases.

Second mitochondria-derived activator of caspase/direct inhibitor of apoptosis-binding protein with low pI (Smac/Diablo) is a protein that homo-dimerizes [113] and that is released from mitochondria in response to apoptotic stimuli [28]. In the cytoplasm, Smac inhibits IAPs by binding to their BIR domains. For example, Smac dimers need to interact with both the BIR2 and BIR3 domains to be able to inhibit XIAP [114,115]. Binding of Smac to IAPs relieves the inhibitory action of IAPs on caspases that are then more easily activated. Smac may also directly activate caspase-3, at least in vitro [113]. Strategies to induce apoptosis in cancer cells are often based on peptides mimicking the IAPbinding motif of proteins with the expectation that such peptides would prevent IAPs from interacting and inhibiting caspases.

\section{Smac-Derived Peptides}

The majority of the peptides designed to inhibit IAPs are based on Smac-derived peptides. The group of Yigong Shi defined that the four first amino acids of the N-terminus of Smac (AVPI) are responsible for the binding to the BIR3 domain of XIAP [116]. This knowledge was used to create a cell-permeable peptide composed of the TAT CPP linked to the seven first amino acids of Smac [117]. The resulting peptide was able to sensitize neuroblastoma cells, and other cancer cell lines, towards TRAIL-, CD95- and chemotherapy induced apoptosis. Three other malignant glioma cell lines were sensitized against doxorubicin, cisplatin and etoposide. Interestingly, four non-malignant human cell lines were not responsive to the peptide, highlighting the cancer-specificity 
of this approach. A complete eradication of pre-established gliomas was found in mice that were treated with the combination of TRAIL and the Smac peptide, while only a decrease in tumor volume was found when each treatment were performed independently.

Other ensuing studies showed that Smac peptides linked to other CPPs, like penetratin or polyarginine, mediated or sensitized cell death in different cancer-type contexts, including breast cancer [118], lymphoma [119], glioblastoma [120] and non-small cell lung cancer [121]. Most of these peptidic versions were shown to restore the sensitivity of cancer cells to different chemotherapies by removing the inhibitory effect of IAPs (such as XIAP, cIAP-1 and cIAP-2) on caspase- 3,7 and 9.

The first four amino acids of Smac are crucially required for its binding to XIAP [116]. The fourth amino acid in this sequence is however the least sterically hindered [116]. Modification of this sequence to improve the binding of Smac to its effectors was therefore thought best attempted at this position. Indeed, conversion of the fourth isoleucine into phenylalanine resulted in a great improvement of Smac binding to XIAP [122]. As Smac functions as a dimer, it was hypothesized that bivalent Smac-derived peptides would be more efficacious. Using the phenylalanine-modified version of the Smac N-terminal tetrapeptide, a dimer linked by the flexible adipic acid was generated and found to be 10'000 fold more potent than the monomer version in binding to the BIR2 and BIR3 of XIAP [123]. Cell-permeable versions of this bivalent Smac peptide will hopefully be developed soon to determine their functional efficacy as apoptosis-promoting tools in cancer cells.

Most studies about inhibition of IAPs are focusing on XIAP because it has a wide and ubiquitous expression and because it is the most potent and versatile member of its family [112]. However, other IAPs, such as ML-IAP, have also been studied to determine if they could be inhibited by peptide-based constructs. ML-IAP, also known as livin or KIAP, bears only one BIR domain (BIR2) that interacts with caspase-3, 7 and 9. It is widely expressed in melanoma cell lines but not in most normal tissues [124, 125]. This expression pattern makes ML-IAP an interesting target for the development of anti-melanoma drugs. In this context, work has been performed to improve the binding and specificity of Smac-derived peptides towards ML-IAP [126]. Promisingly, modifications of selected residues in the Smac N-terminal sequence resulted in a peptide that displayed a 100 times greater specificity for ML-IAP-BIR relative to XIAP-BIR3 [126].

\section{Survivin-Derived Peptides}

Survivin is one of the most interesting IAP members in the context of cancer therapy because, in contrast to many IAPs, it is generally not expressed in adult tissues but very often over-expressed in tumors [127]. A transcriptomic analysis singled out survivin as the fourth "most cancerspecific of all gene products" [46]. Survivin confers apoptosis protection by antagonizing caspases. It does so mainly by cooperating with other proteins such as HBXIP to inhibit caspase- 9 , by favoring the stability of XIAP, or by competing with Smac [128]. Additionally, survivin has functions distinct from regulation of apoptosis by playing very important roles during cell division $[127,128]$. The implication of survivin in both the control of cell division and the survival of cells makes it a prime target for the development of anticancer strategies.

The interaction with the HSP90 chaperone is essential for survivin stability. An amino acid stretch within the BIR survivin is required for this interaction to occur [129]. The laboratory of Dario Altieri used the minimal number of amino acids required for survivin binding to HSP90 (K79-L87), which they called "shepherdin", to down-regulate survivin levels in cells [130]. They produced a cell-permeable peptide encoding the K79-L87 sequence and found that it selectively killed tumor, but not normal, cells [130]. The ability of shepherdin to kill cells was p53-independent, an important property in the context of cancer therapy as most tumor cells have lost a functional p53 pathway. Interestingly, shepherdin also prevented HSP90 from binding to and stabilizing other of its client proteins, including well-known pro-cancer proteins such as Akt [130]. In addition, in vivo experiments validated the efficacy of a retro-inverso version of shepherdin in immunocompromised mice bearing xenograft tumors, as well as in a mammary cancer mouse model [130]. The broad spectrum of cancer cell types targeted by shepherdin coupled to its apparent lack of adverse effect on normal tissues makes this peptide one of the most promising anti-tumor peptidebased candidates currently available. As survivin plays a crucial role during cell division, the impact of shepherdin on organs that display high tissue renewing, such as the intestine, will have to be monitored very closely though.

\section{p53-Derived Peptides}

p53 is one of the best known tumor suppressors [131]. It is a stress and oncogenic sensor able to either inhibit cell cycle for repair or induce apoptosis [131]. The ability of p53 to counteract cancer development is best correlated with its apoptosis-inducing capacity [132]. Unsurprisingly, p53, and p53 regulators, are mutated in many human cancers so as to render the p53 pathway ineffective [131,132]. This correlates with poor prognosis [133]. Restoration of a functional p53 apoptosis signaling response in cancer cells represents therefore an attractive approach to fight cancer development. In a pioneer work [134], David Lane and colleagues synthesized a 15 amino acid long peptide derived from a carboxyterminal domain of p53 that negatively regulates its own transcriptional activity and showed that this peptide can activate latent forms of p53 when injected into cells. The peptide was thus relieving the auto-inhibitory function of the Cterminal sequences of p53. Importantly in the context of cancer therapy, the peptide was able to activate several p53 mutants [135] and induce the death of the cells expressing those mutants [136]. Despite its ability to activate wild-type p53, the C-terminal p53 peptide does not induce apoptosis in primary cells [136] presumably because of low p53 expression and absence of oncogenic apoptosis-prone signals in normal cells. Based on these earlier findings, the laboratory of Steven Dowdy developed a retro-inverso cell-permeable version of the p53 peptide by coupling it to the HIV-TAT CPP. The resulting peptide, called RI-TATp53C', when injected into mice, inhibited the growth of sub-cutaneous tumors, peritoneal carcinomas and lymphomas [137]. To assess whether 
the RI-TATp53C' could be modified so as to target cancer cells more specifically, the same laboratory hooked to the peptide the DV3 domain from the CXC chemokine receptor4 (CXCR4) ligand [138]. The CXCR4 ligand appears particularly suited here because it is small, its receptor CXCR4 is over-expressed on many tumor cell types, and importantly its synthesis using D-amino acids does not adversely affect its ability to bind CXCR4 [139]. Compared to the unmodified RI-TATp53C' peptide, the DV3-RI-TATp53C' peptide in vitro had a stronger apoptotic activity in CXCR4expressing tumors. Both peptides had similar killing activities in non-CXCR4-expressing tumor cells [138]. It will now have to be determined if the DV3-RI-TATp53C' peptide has increased CXCR4-specific anti-tumor activity in vivo.

Recently, the group of Giannino Del Sal created a series of mutant p53-targeting peptide aptamers [140]. Aptamers consist of short variable peptides expressed on a constant presenting structure that are generated in combinatorial libraries and that can be used to select sequences able to bind to proteins or structures of interest [141]. The identified aptamers were able to induce apoptosis in mutant p53expressing tumor cells but they had no effect on cancer cells lacking p53 or expressing wild-type p53 [140]. However, these aptamers did not reactivate the wild-type functions of p53 (e.g. induction of p21 transcription). How they induce death in p53 mutant expressing cells remain therefore to be determined.

\section{Natural Peptides}

The discovery of taxol as a potent anti-cancerous compound [142] is an emblematic example of the usefulness of natural product drug discovery programs (and a reminder of the importance of preserving bio-diversity on our planet). And indeed, a series of natural peptides have been identified as potential anti-cancer compounds. The following is a non exhaustive list of examples. Cecropins (CB) are antimicrobial 34- to 39-mer peptides found in the hemolymph of the Cecropia moth (Hyalophora cecropia), the largest North American moth. Some of them were shown to kill HL-60 leukemia cells with minimal effects on non-tumoral 3T3 fibroblasts [143]. Magainins are a class of peptides isolated from Xenopus laevis skin that are able to form pores and thereby lyse hematopoietic tumors with a relatively low cytotoxicity against differentiated tissues [144]. Melittin, a 26 amino acid-long peptide isolated from the bee venom, appears to preferentially kill cancer cells over-expressing Ras [145]. Additional anti-cancer peptides have been isolated from very varied sources, including rapeseed (Brassica napus) [146], soy (Glycine max) [147], the grouper Epinephelus coioides [148], the marine mollusc Dolabella auricularia [149], and even humans [150]. The anti-tumoral properties of natural peptides may not be potent and selective enough to allow these compounds to be used as is in humans. They however offer the base for further development and modifications to increase their efficacy as anti-cancer compounds, as shown recently for cecropins [151].

\section{CONCLUSION}

This review was aiming at showing the breadth of anticancer peptide research. The majority of the peptides dis- cussed here display important anti-cancer activities in vitro, and many were tested and validated in vivo for their effect on tumor development. Some anti-cancer peptides are now used in clinical studies [9]. However, none so far have the ability to home specifically to their targets, even though many induce a stronger death response in tumor cells than in normal tissues. It may therefore be very valuable to modify antitumor peptides so that they only target cancer cells. As indicated in this review, a vast number of apoptosis-inducing or apoptosis-sensitizing peptides already exist. Moreover, the targeting methods and the mode of peptide delivery in vivo are constantly being improved. One of the next challenges in this field will be to determine the best match between the peptide bearing the anti-cancer activity and the chemical modifications or additions that will help the peptide discriminate better between normal and tumor cells. Another research axis will be to determine whether combinations of anti-cancer peptides and drugs currently used in the clinic to treat cancers display synergistic therapeutic efficacy. Hopefully, this research will soon lead to the development of antitumor therapeutical peptides that will be efficacious in treating cancer patients.

\section{ACKNOWLEDGEMENTS}

C.W. is supported by grants from the Swiss National Science Foundation. We would like to thank Dr. Cécile Billotte, Nieves Peltzer and Alessandro Annibaldi for critical reading of this review, as well as for their constructive comments. Because of space constraints, we apologize to the research groups whose citations were omitted or cited indirectly.

\section{CONFLICT OF INTEREST}

C. Widmann is a coinventor of the TAT-RasGAP $317-326$ compound as a genotoxin sensitizer (patent owned by the University of Lausanne) and may receive royalties from patent licensing if this peptide is commercialized. The authors did not receive any specific support from private or institutional bodies that might have commercial interests in the patented product.

\section{REFERENCES}

[1] Jemal, A., Siegel, R., Ward, E., Hao, Y., Xu, J., Thun, M.J. Cancer statistics, 2009. CA Cancer J. Clin., 2009, 59(4), 225-249.

[2] Hanahan, D.; Weinberg, R.A. The hallmarks of cancer. Cell, 2000, $100(1), 57-70$

[3] Annibaldi, A.; Widmann, C. Glucose metabolism in cancer cells. Curr. Opin. Clin. Nutr. Metab. Care., 2010, 13, 466-470.

[4] Yeung, S.J.; Pan, J.; Lee, M.H. Roles of p53, MYC and HIF-1 in regulating glycolysis - the seventh hallmark of cancer. Cell Mol. Life Sci., 2008, 65(24), 3981-3999.

[5] Vander Heiden, M.G.; Cantley, L.C.; Thompson, C.B. Understanding the Warburg effect: the metabolic requirements of cell proliferation. Science, 2009, 324(5930), 1029-1033.

[6] Mendoza, F.J.; Espino, P.S.; Cann, K.L.; Bristow, N.; McCrea, K.; Los, M. Anti-tumor chemotherapy utilizing peptide-based approaches--apoptotic pathways, kinases, and proteasome as targets. Arch Immunol. Ther. Exp. (Warsz. ), 2005, 53(1), 47-60.

[7] Khandare, J.J.; Minko, T. Antibodies and peptides in cancer therapy. Crit Rev. Ther. Drug Carrier Syst., 2006, 23(5), 401-435.

[8] Michod, D.; Widmann, C. DNA-damage sensitizers: potential new therapeutical tools to improve chemotherapy. Crit Rev. Oncol. Hematol., 2007, 63(2), 160-171.

[9] Stevenson, C.L. Advances in peptide pharmaceuticals. Curr. Pharm. Biotechnol., 2009, 10(1), 122-137. 
[10] Bidwell, G.L.; III Raucher, D. Therapeutic peptides for cancer therapy. Part I - peptide inhibitors of signal transduction cascades. Expert. Opin. Drug Deliv., 2009, 6(10), 1033-1047.

[11] Raucher, D.; Moktan, S.; Massodi, I.; Bidwell, G.L. III Therapeutic peptides for cancer therapy. Part II - cell cycle inhibitory peptides and apoptosis-inducing peptides. Expert. Opin. Drug Deliv., 2009, 6(10), 1049-1064

[12] Bitler, B.G.; Schroeder, J.A. Anti-cancer therapies that utilize cell penetrating peptides. Recent Pat. Anticancer Drug Discov., 2010, 5 , in press

[13] Cande, C.; Cecconi, F.; Dessen, P.; Kroemer, G. Apoptosisinducing factor (AIF): key to the conserved caspase-independent pathways of cell death? J. Cell Sci., 2002, 115(Pt 24), 4727-4734

[14] Taylor, R.C.; Cullen, S.P.; Martin, S.J. Apoptosis: controlled demolition at the cellular level. Nat. Rev. Mol. Cell Biol., 2008, 9(3), 231-241

[15] Evan, G.I.; Vousden, K.H. Proliferation, cell cycle and apoptosis in cancer. Nature, 2001, 411(6835), 342-348

[16] Debatin, K.M. Apoptosis pathways in cancer and cancer therapy. Cancer Immunol. Immunother., 2004, 53(3), 153-159

[17] Bos, J.L.; Rehmann, H.; Wittinghofer, A. GEFs and GAPs: critical elements in the control of small G proteins. Cell, 2007, 129(5), 865-877

[18] Savill, J.; Fadok, V. Corpse clearance defines the meaning of cell death. Nature, 2000, 407(6805), 784-788

[19] He, B.; Lu, N.; Zhou, Z. Cellular and nuclear degradation during apoptosis. Curr. Opin. Cell Biol., 2009, 21(6), 900-912

[20] Weigert, A.; Jennewein, C.; Brune, B. The liaison between apoptotic cells and macrophages--the end programs the beginning. Biol. Chem., 2009, 390(5-6), 379-390

[21] Paidassi, H.; Tacnet-Delorme, P.; Arlaud, G.J.; Frachet, P. How phagocytes track down and respond to apoptotic cells. Crit. Rev. Immunol., 2009, 29(2), 111-130

[22] Riedl, S.J.; Shi, Y. Molecular mechanisms of caspase regulation during apoptosis. Nat. Rev. Mol. Cell Biol., 2004, 5(11), 897-907

[23] Kumar, S. Caspase 2 in apoptosis, the DNA damage response and tumour suppression: enigma no more? Nat. Rev. Cancer, 2009, 9(12), 897-903

[24] Cain, K.; Bratton, S.B.; Cohen, G.M. The Apaf-1 apoptosome: a large caspase-activating complex. Biochimie., 2002, 84(2-3), 203214

[25] Youle, R.J.; Strasser, A. The BCL-2 protein family: opposing activities that mediate cell death. Nat. Rev. Mol. Cell Biol., 2008, 9(1), 47-59

[26] Nachmias, B.; Ashhab, Y.; Ben Yehuda, D. The inhibitor of apoptosis protein family (IAPs): an emerging therapeutic target in cancer. Semin. Cancer Biol., 2004, 14(4), 231-243

[27] Vaux, D.L.; Silke, J. IAPs, RINGs and ubiquitylation. Nat. Rev, Mol. Cell Biol., 2005, 6(4), 287-297

[28] Martinez-Ruiz, G.; Maldonado, V.; Ceballos-Cancino, G.; Grajeda, J.P.; Melendez-Zajgla, J. Role of Smac/DIABLO in cancer progression. J. Exp. Clin. Cancer Res., 2008, 27, 48

[29] Gorgoulis, V.G.; Vassiliou, L.V.; Karakaidos, P.; Zacharatos, P.; Kotsinas, A., Liloglou, T.; Venere, M.; Ditullio, R.A. Jr.; Kastrinakis, N.G.; Levy, B.; Kletsas, D.; Yoneta, A.; Herlyn, M.; Kittas, C.; Halazonetis, T.D. Activation of the DNA damage checkpoint and genomic instability in human precancerous lesions. Nature, 2005, 434(7035), 907-913

[30] Merino, D.; Lalaoui, N.; Morizot, A.; Solary, E.; Micheau, O. TRAIL in cancer therapy: present and future challenges. Expert. Opin. Ther. Targets, 2007, 11(10), 1299-1314

[31] Fulda, S. Tumor resistance to apoptosis. Int. J. Cancer, 2009, 124(3), 511-515

[32] Green, M.; Loewenstein, P.M. Autonomous functional domains of chemically synthesized human immunodeficiency virus tat transactivator protein. Cell, 1988, 55(6), 1179-1188

[33] Frankel, A.D.; Pabo, C.O. Cellular uptake of the tat protein from human immunodeficiency virus. Cell, 1988, 55(6), 1189-1193

[34] Fawell, S.; Seery, J;, Daikh, Y.; Moore, C.; Chen, L.L.; Pepinsky, B.; Barsoum, J. Tat-mediated delivery of heterologous proteins into cells. Proc. Natl. Acad. Sci. USA, 1994, 91(2), 664-668

[35] Nagahara, H.; Vocero-Akbani, A.M.; Snyder, E.L.; Ho, A.; Latham, D.G.; Lissy, N.A.; Becker-Hapak, M.; Ezhevsky, S.A.; Dowdy, S.F. Transduction of full-length TAT fusion proteins into mammalian cells: TAT-p27Kip1 induces cell migration. Nat. Med., 1998, 4(12), 1449-1452
[36] Vives, E.; Brodin, P.; Lebleu, B. A truncated HIV-1 Tat protein basic domain rapidly translocates through the plasma membrane and accumulates in the cell nucleus. J. Biol. Chem., 1997, 272(25), 16010-16017

[37] Heitz, F.; Morris, M.C.; Divita, G. Twenty years of cell-penetrating peptides: from molecular mechanisms to therapeutics. $\mathrm{Br}$. J. Pharmacol., 2009, 157(2), 195-206

[38] Derossi, D.; Joliot, A.H.; Chassaing, G.; Prochiantz, A. The third helix of the Antennapedia homeodomain translocates through biological membranes. J. Biol. Chem., 1994, 269(14), 10444-10450

[39] Elliott, G.; O'Hare, P. Intercellular trafficking and protein delivery by a herpesvirus structural protein. Cell, 1997, 88(2), 223-233

[40] Gros, E.; Deshayes, S.; Morris, M.C.; drian-Herrada, G.; Depollier, J.; Heitz, F.; Divita, G. A non-covalent peptide-based strategy for protein and peptide nucleic acid transduction. Biochim. Biophys. Acta, 2006, 1758(3), 384-393

[41] Futaki, S.; Suzuki, T.; Ohashi, W.; Yagami, T.; Tanaka, S.; Ueda, K.; Sugiura, Y. Arginine-rich peptides. An abundant source of membrane-permeable peptides having potential as carriers for intracellular protein delivery. J. Biol. Chem., 2001, 276(8), 58365840

[42] Aroui, S.; Brahim, S.; Hamelin, J.; De, W.M.; Breard, J.; Kenani, A. Conjugation of doxorubicin to cell penetrating peptides sensitizes human breast MDA-MB 231 cancer cells to endogenous TRAIL-induced apoptosis. Apoptosis., 2009, 14(11), 1352-1365

[43] Schwarze, S.R.; Ho, A.; Vocero-Akbani, A.; Dowdy, S.F. In vivo protein transduction: delivery of a biologically active protein into the mouse. Science, 1999, 285(5433), 1569-1572

[44] Takayama, K.; Nakase, I.; Michiue, H.; Takeuchi, T.; Tomizawa, K.; Matsui, H.; Futaki, S. Enhanced intracellular delivery using arginine-rich peptides by the addition of penetration accelerating sequences (Pas). J. Control Release, 2009, 138(2), 128-133

[45] Fischer, P.M. The design, synthesis and application of stereochemical and directional peptide isomers: a critical review. Curr. Protein Pept. Sci., 2003, 4(5), 339-356

[46] Velculescu, V.E.; Madden, S.L.; Zhang, L.; Lash, A.E.; Yu, J.; Rago, C.; Lal, A.; Wang, C.J.; Beaudry, G.A.; Ciriello, K.M.; Cook, B.P.; Dufault, M.R.; Ferguson, A.T.; Gao, Y.; He, T.C.; Hermeking, H.; Hiraldo, S.K.; Hwang, P.M.; Lopez, M.A.; Luderer, H.F.; Mathews, B.; Petroziello, J.M.; Polyak, K.; Zawel, L.; Kinzler, K.W. Analysis of human transcriptomes. Nat. Genet., 1999, 23(4), 387-388

[47] Lee, A.S. GRP78 induction in cancer: therapeutic and prognostic implications. Cancer Res., 2007, 67(8), 3496-3499

[48] Arap, M.A.; Lahdenranta, J.; Mintz, P.J.; Hajitou, A.; Sarkis, A.S.; Arap, W.; Pasqualini, R. Cell surface expression of the stress response chaperone GRP78 enables tumor targeting by circulating ligands. Cancer Cell, 2004, 6(3), 275-284

[49] Yip, K.W.; Reed, J.C. Bcl-2 family proteins and cancer. Oncogene, 2008, 27(50), 6398-6406

[50] Frenzel, A.; Grespi, F.; Chmelewskij, W.; Villunger, A. Bcl2 family proteins in carcinogenesis and the treatment of cancer. Apoptosis, 2009, 14(4), 584-596

[51] Brunelle, J.K.; Letai, A. Control of mitochondrial apoptosis by the Bcl-2 family. J. Cell Sci., 2009, 122(Pt 4), 437-441

[52] Chen, R.; Valencia, I.; Zhong, F.; McColl, K.S.; Roderick, H.L.; Bootman, M.D.; Berridge, M.J.; Conway, S.J.; Holmes, A.B.; Mignery, G.A.; Velez, P.; Distelhorst, C.W. Bcl-2 functionally interacts with inositol 1,4,5-trisphosphate receptors to regulate calcium release from the ER in response to inositol 1,4,5trisphosphate. J. Cell Biol., 2004, 166(2), 193-203

[53] Minn, A.J.; Boise, L.H.; Thompson, C.B. Bcl-x(S) anatagonizes the protective effects of Bcl-x(L). J. Biol. Chem., 1996, $271(11), 6306-$ 6312

[54] Inohara, N.; Gourley, T.S.; Carrio, R.; Muniz, M.; Merino, J.; Garcia, I.; Koseki, T.; Hu, Y.; Chen, S.; Nunez, G. Diva, a Bcl-2 homologue that binds directly to Apaf-1 and induces BH3independent cell death. J. Biol. Chem., 1998, 273(49), 3247932486

[55] Korsmeyer, S.J.; Wei, M.C.; Saito, M.; Weiler, S.; Oh, K.J.; Schlesinger, P.H. Pro-apoptotic cascade activates BID, which oligomerizes BAK or BAX into pores that result in the release of cytochrome c. Cell Death. Differ., 2000, 7(12), 1166-1173

[56] Kuwana, T.; Bouchier-Hayes, L.; Chipuk, J.E.; Bonzon, C.; Sullivan, B.A.; Green, D.R.; Newmeyer, D.D. BH3 domains of BH3-only proteins differentially regulate Bax-mediated 
mitochondrial membrane permeabilization both directly and indirectly. Mol. Cell, 2005, 17(4), 525-535

[57] Fletcher, J.I.; Huang, D.C. Controlling the cell death mediators Bax and Bak: puzzles and conundrums. Cell Cycle, 2008, 7(1), 39-44

[58] Gavathiotis, E.; Suzuki, M.; Davis, M.L.; Pitter, K.; Bird, G.H.; Katz, S.G.; Tu, H.C.; Kim, H.; Cheng, E.H.; Tjandra, N.; Walensky, L.D. BAX activation is initiated at a novel interaction site. Nature, 2008, 455(7216), 1076-1081

[59] Adams, J.M.; Cory, S. The Bcl-2 protein family: arbiters of cell survival. Science, 1998, 281, 1322-1326

[60] Chao, D.T.; Korsmeyer, S.J. BCL-2 family: regulators of cell death. Annu. Rev. Immunol., 1998, 16, 395-419

[61] Zuo, J.; Ishikawa, T.; Boutros, S.; Xiao, Z.; Humtsoe, J.O.; Kramer, R.H. Bcl-2 overexpression induces a partial epithelial to mesenchymal transition and promotes squamous carcinoma cell invasion and metastasis. Mol. Cancer Res., 2010, 8(2), 170-182

[62] Chen, L.; Willis, S.N.; Wei, A.; Smith, B.J.; Fletcher, J.I.; Hinds, M.G.; Colman, P.M.; Day, C.L.; Adams, J.M.; Huang, D.C. Differential targeting of prosurvival Bcl-2 proteins by their BH3only ligands allows complementary apoptotic function. Mol. Cell, 2005, 17(3), 393-403

[63] Wang, C.; Youle, R.J. The role of mitochondria in apoptosis. Annu. Rev. Genet., 2009, 43, 95-118

[64] Sattler, M.; Liang, H.; Nettesheim, D.; Meadows, R.P.; Harlan, J.E.; Eberstadt, M.; Yoon, H.S.; Shuker, S.B.; Chang, B.S.; Minn, A.J.; Thompson, C.B.; Fesik, S.W. Structure of Bcl-X $\mathrm{L}_{\mathrm{L}}$-Bak peptide complex: recognition between regulators of apoptosis. Science, 1997, 275, 983-986

[65] Holinger, E.P.; Chittenden, T.; Lutz, R.J. Bak BH3 peptides antagonize Bcl-xL function and induce apoptosis through cytochrome c-independent activation of caspases. J. Biol. Chem., 1999, 274(19), 13298-13304

[66] Dharap, S.S.; Minko, T. Targeted proapoptotic LHRH-BH3 peptide. Pharm. Res., 2003, 20(6), 889-896

[67] Dharap, S.S.; Wang, Y.; Chandna, P.; Khandare, J.J.; Qiu, B.; Gunaseelan, S.; Sinko, P.J.; Stein, S.; Farmanfarmaian, A.; Minko, T. Tumor-specific targeting of an anticancer drug delivery system by LHRH peptide. Proc. Natl. Acad. Sci. USA, 2005, 102(36), 12962-12967

[68] Forastiere, A.; Koch, W.; Trotti, A.; Sidransky, D. Head and neck cancer. N. Engl. J. Med., 2001, 345(26), 1890-1900

[69] Ratushny, V.; Astsaturov, I.; Burtness, B.A.; Golemis, E.A.; Silverman, J.S. Targeting EGFR resistance networks in head and neck cancer. Cell Signal., 2009, 21(8), 1255-1268

[70] Danial, N.N.; Korsmeyer, S.J. Cell death: critical control points. Cell, 2004, 116(2), 205-219

[71] Li, R.; Boehm, A.L.; Miranda, M.B.; Shangary, S.; Grandis, J.R.; Johnson, D.E. Targeting antiapoptotic Bcl-2 family members with cell-permeable BH3 peptides induces apoptosis signaling and death in head and neck squamous cell carcinoma cells. Neoplasia, 2007, 9(10), 801-811

[72] Yin, X.M.; Oltvai, Z.N.; Korsmeyer, S.J. BH1 and BH2 domains of Bcl-2 are required for inhibition of apoptosis and heterodimerization with Bax. Nature, 1994, 369(6478), 321-323

[73] Diaz, J.L.; Oltersdorf, T.; Horne, W.; McConnell, M.; Wilson, G.; Weeks, S.; Garcia, T.; Fritz, L.C. A common binding site mediates heterodimerization and homodimerization of $\mathrm{Bcl}-2$ family members. J. Biol. Chem., 1997, 272(17), 11350-11355

[74] Narita, M.; Shimizu, S.; Ito, T.; Chittenden, T.; Lutz, R.J.; Matsuda, H.; Tsujimoto, Y. Bax interacts with the permeability transition pore to induce permeability transition and cytochrome c release in isolated mitochondria. Proc. Natl. Acad. Sci. USA, 1998, 95(25), 14681-14686

[75] Finnegan, N.M.; Curtin, J.F.; Prevost, G.; Morgan, B.; Cotter, T.G. Induction of apoptosis in prostate carcinoma cells by $\mathrm{BH} 3$ peptides which inhibit Bak/Bcl-2 interactions. Br. J. Cancer, 2001, 85(1), $115-121$

[76] Juin, P.; Hunt, A.; Littlewood, T.; Griffiths, B.; Swigart, L.B.; Korsmeyer, S.; Evan, G. c-Myc functionally cooperates with Bax to induce apoptosis. Mol. Cell Biol., 2002, 22(17), 6158-6169

[77] Shangary, S.; Oliver, C.L.; Tillman, T.S.; Cascio, M.; Johnson, D.E. Sequence and helicity requirements for the proapoptotic activity of Bax BH3 peptides. Mol. Cancer Ther., 2004, 3(11), 1343-1354

[78] Moreau, C.; Cartron, P.F.; Hunt, A.; Meflah, K.; Green, D.R.; Evan, G.; Vallette, F.M.; Juin, P. Minimal BH3 peptides promote cell death by antagonizing anti-apoptotic proteins. J. Biol. Chem., 2003, 278(21), 19426-19435

[79] Wood, D.E.; Thomas, A.; Devi, L.A.; Berman, Y.; Beavis, R.C.; Reed, J.C.; Newcomb, E.W. Bax cleavage is mediated by calpain during drug-induced apoptosis. Oncogene, 1998, 17(9), 1069-1078

[80] Gao, G.; Dou, Q.P. N-terminal cleavage of bax by calpain generates a potent proapoptotic $18-\mathrm{kDa}$ fragment that promotes bcl2 -independent cytochrome $\mathrm{C}$ release and apoptotic cell death. $J$. Cell Biochem., 2000, 80(1), 53-72

[81] Li, N.; Lin, P.; Cai, C.; Pan, Z.; Weisleder, N.; Ma, J. The aminoterminal peptide of Bax perturbs intracellular $\mathrm{Ca} 2+$ homeostasis to enhance apoptosis in prostate cancer cells. Am. J. Physiol. Cell Physiol., 2009, 296(2), C267-C272

[82] Monteith, G.R.; McAndrew, D.; Faddy, H.M.; Roberts-Thomson, S.J. Calcium and cancer: targeting $\mathrm{Ca} 2+$ transport. Nat. Rev. Cancer, 2007, 7(7), 519-530

[83] Nakano, K.; Vousden, K.H. PUMA, a novel proapoptotic gene, is induced by p53. Mol. Cell, 2001, 7(3), 683-694

[84] Yu, J.; Wang, Z.; Kinzler, K.W.; Vogelstein, B.; Zhang, L. PUMA mediates the apoptotic response to p53 in colorectal cancer cells. Proc. Natl. Acad. Sci. USA, 2003, 100(4), 1931-1936

[85] Villunger, A.; Michalak, E.M.; Coultas, L.; Mullauer, F.; Bock, G.; Ausserlechner, M.J.; Adams, J.M.; Strasser, A. p53- and druginduced apoptotic responses mediated by $\mathrm{BH} 3$-only proteins puma and noxa. Science, 2003, 302(5647), 1036-1038

[86] Liu, Y.; Li, Y.; Wang, H.; Yu, J.; Lin, H.; Xu, D.; Wang, Y.; Liang, A.; Liang, X.; Zhang, X.; Fu, M.; Qian, H.; Lin, C. BH3-based fusion artificial peptide induces apoptosis and targets human colon cancer. Mol. Ther., 2009, 17(9), 1509-1516

[87] Ming, L.; Wang, P.; Bank, A.; Yu, J.; Zhang, L. PUMA Dissociates Bax and Bcl-X(L) to induce apoptosis in colon cancer cells. J. Biol. Chem., 2006, 281(23), 16034-16042

[88] Balkwill, F. The significance of cancer cell expression of the chemokine receptor CXCR4. Semin. Cancer Biol., 2004, 14(3), 171-179

[89] Michod, D.; Yang, J.Y.; Chen, J.; Bonny, C.; Widmann, C. A RasGAP-derived cell permeable peptide potently enhances genotoxin-induced cytotoxicity in tumor cells. Oncogene, 2004, 23(55), 8971-8978

[90] Yang, J.-Y.; Widmann, C. Antiapoptotic signaling generated by caspase-induced cleavage of RasGAP. Mol. Cell. Biol., 2001, 21, 5346-5358

[91] Yang, J.-Y.; Michod, D.; Walicki, J.; Murphy, B.M.; Kasibhatla, S.; Martin, S.; Widmann, C. Partial cleavage of RasGAP by caspases is required for cell survival in mild stress conditions. Mol. Cell Biol., 2004, 24(23), 10425-10436

[92] Michod, D.; Annibaldi, A.; Schaefer, S.; Dapples, C.; Rochat, B.; Widmann, C. Effect of RasGAP N2 fragment-derived peptide on tumor growth in mice. J. Natl. Cancer Inst., 2009, 101(11), 828832

[93] Michod, D.; Widmann, C. TAT-RasGAP ${ }_{317-326}$ requires p53 and PUMA to sensitize tumor cells to genotoxins. Mol. Cancer Res., 2007, 5(5), 497-507

[94] Yang, E.; Zha, J.; Jockel, J.; Boise, L.H.; Thompson, C.B.; Korsmeyer, S.J. Bad, a heterodimeric partner for Bcl-XL and Bcl2, displaces Bax and promotes cell death. Cell, 1995, 80(2), 285291

[95] Kelekar, A.; Chang, B.S.; Harlan, J.E.; Fesik, S.W.; Thompson, C.B. Bad is a $\mathrm{BH} 3$ domain-containing protein that forms an inactivating dimer with Bcl-XL. Mol. Cell Biol., 1997, 17(12), 7040-7046

[96] Wang, J.L.; Zhang, Z.J.; Choksi, S.; Shan, S.; Lu, Z.; Croce, C.M.; Alnemri, E.S.; Korngold, R.; Huang, Z. Cell permeable Bcl-2 binding peptides: a chemical approach to apoptosis induction in tumor cells. Cancer Res., 2000, 60(6), 1498-1502

[97] Schimmer, A.D.; Hedley, D.W.; Chow, S.; Pham, N.A.; Chakrabartty, A.; Bouchard, D.; Mak, T.W.; Trus, M.R.; Minden, M.D. The BH3 domain of BAD fused to the Antennapedia peptide induces apoptosis via its alpha helical structure and independent of Bcl-2. Cell Death. Differ., 2001, 8(7), 725-733

[98] Blondelle, S.E.; Houghten, R.A. Design of model amphipathic peptides having potent antimicrobial activities. Biochemistry, 1992, 31(50), 12688-12694

[99] Tossi, A.; Sandri, L.; Giangaspero, A. Amphipathic, alpha-helical antimicrobial peptides. Biopolymers, 2000, 55(1), 4-30 
[100] Ellerby, H.M.; Arap, W.; Ellerby, L.M.; Kain, R.; Andrusiak, R.; Rio, G.D.; Krajewski, S.; Lombardo, C.R.; Rao, R.; Ruoslahti, E.; Bredesen, D.E.; Pasqualini, R. Anti-cancer activity of targeted proapoptotic peptides. Nat. Med., 1999, 5(9), 1032-1038

[101] Shangary, S.; Johnson, D.E. Peptides derived from BH3 domains of Bcl-2 family members: a comparative analysis of inhibition of Bcl$2, \mathrm{Bcl}-\mathrm{x}(\mathrm{L})$ and $\mathrm{Bax}$ oligomerization, induction of cytochrome $\mathrm{c}$ release, and activation of cell death. Biochemistry, 2002, 41(30), 9485-9495

[102] Walensky, L.D.; Kung, A.L.; Escher, I.; Malia, T.J.; Barbuto, S.; Wright, R.D.; Wagner, G.; Verdine, G.L.; Korsmeyer, S.J. Activation of apoptosis in vivo by a hydrocarbon-stapled $\mathrm{BH} 3$ helix. Science, 2004, 305(5689), 1466-1470

[103] McGrogan, B.T.; Gilmartin, B.; Carney, D.N.; McCann, A Taxanes, microtubules and chemoresistant breast cancer. Biochim. Biophys. Acta, 2008, 1785(2), 96-132

[104] Li, R.; Moudgil, T.; Ross, H.J.; Hu, H.M. Apoptosis of non-smallcell lung cancer cell lines after paclitaxel treatment involves the BH3-only proapoptotic protein Bim. Cell Death. Differ., 2005, 12(3), 292-303

[105] Sunters, A.; Fernandez de, M.S.; Stahl, M.; Brosens, J.J.; Zoumpoulidou, G.; Saunders, C.A.; Coffer, P.J.; Medema, R.H.; Coombes, R.C.; Lam, E.W. FoxO3a transcriptional regulation of Bim controls apoptosis in paclitaxel-treated breast cancer cell lines. J. Biol. Chem., 2003, 278(50), 49795-49805

[106] Kashiwagi, H.; McDunn, J.E.; Goedegebuure, P.S.; Gaffney, M.C.; Chang, K.; Trinkaus, K.; Piwnica-Worms, D.; Hotchkiss, R.S.; Hawkins, W.G. TAT-Bim induces extensive apoptosis in cancer cells. Ann. Surg. Oncol., 2007, 14(5), 1763-1771

[107] Cory, S.; Huang, D.C. Adams, J.M. The Bcl-2 family: roles in cell survival and oncogenesis. Oncogene, 2003, 22(53), 8590-8607

[108] Huang, D.C.S.; Adams, J.M.; Cory, S. The conserved N-terminal $\mathrm{BH} 4$ domain of Bcl-2 homologues is essential for inhibition of apoptosis and interaction with CED-4. EMBO J., 1998, 17(4), 1029-1039

[109] Rong, Y.P.; Bultynck, G.; Aromolaran, A.S.; Zhong, F.; Parys, J.B.; De, S.H.; Mignery, G.A.; Roderick, H.L.; Bootman, M.D.; Distelhorst, C.W. The BH4 domain of Bcl-2 inhibits ER calcium release and apoptosis by binding the regulatory and coupling domain of the IP3 receptor. Proc. Natl. Acad. Sci. USA, 2009 , 106(34), 14397-14402

[110] Rong, Y.P.; Barr, P.; Yee, V.C.; Distelhorst, C.W. Targeting Bcl-2 based on the interaction of its $\mathrm{BH} 4$ domain with the inositol 1,4,5 trisphosphate receptor. Biochim. Biophys. Acta, 2009, 1793(6), 971-978

[111] Rong, Y.P., Aromolaran, A.S., Bultynck, G.; Zhong, F.; Li, X.; McColl, K.; Matsuyama, S.; Herlitze, S.; Roderick, H.L.; Bootman, M.D.; Mignery, G.A.; Parys, J.B.; De, S.H.; Distelhorst, C.W. Targeting Bcl-2-IP3 receptor interaction to reverse Bcl-2's inhibition of apoptotic calcium signals. Mol. Cell, 2008, 31(2), 255265

[112] Deveraux, Q.L.; Reed, T.C. IAP family proteins - suppressors of apoptosis. Genes Dev., 1999, 13(3), 239-252

[113] Chai, J.; Du, C.; Wu, J.W.; Kyin, S.; Wang, X.; Shi, Y. Structural and biochemical basis of apoptotic activation by Smac/DIABLO. Nature, 2000, 406(6798), 855-862

[114] Huang, Y.; Rich, R.L.; Myszka, D.G.; Wu, H. Requirement of both the second and third BIR domains for the relief of X-linked inhibitor of apoptosis protein (XIAP)-mediated caspase inhibition by Smac. J. Biol. Chem., 2003, 278(49), 49517-49522

[115] Gao, Z.; Tian, Y.; Wang, J.; Yin, Q.; Wu, H.; Li, Y.M.; Jiang, X. A dimeric Smac/diablo peptide directly relieves caspase-3 inhibition by XIAP. Dynamic and cooperative regulation of XIAP by Smac/Diablo. J. Biol. Chem., 2007, 282(42), 30718-30727

[116] Wu, G.; Chai, J.; Suber, T.L.; Wu, J.W.; Du, C.; Wang, X.; Shi, Y. Structural basis of IAP recognition by Smac/DIABLO. Nature, 2000, 408(6815), 1008-1012

[117] Fulda, S.; Wick, W.; Weller, M.; Debatin, K.M. Smac agonists sensitize for Apo2L/T. Nat. Med., 2002, 8(8), 808-815

[118] Arnt, C.R.; Chiorean, M.V.; Heldebrant, M.P.; Gores, G.J.; Kaufmann, S.H. Synthetic Smac/DIABLO peptides enhance the effects of chemotherapeutic agents by binding XIAP and cIAP1 in situ. J. Biol. Chem., 2002, 277(46), 44236-44243

[119] Sun, Y.; Ottosson, A.; Pervaiz, S.; Fadeel, B. Smac-mediated sensitization of human B-lymphoma cells to staurosporine- and lactacystin-triggered apoptosis is apoptosome-dependent. Leukemia, 2007, 21(5), 1035-1043

[120] Mizukawa, K.; Kawamura, A.; Sasayama, T.; Tanaka, K.; Kamei, M.; Sasaki, M.; Kohmura, E. Synthetic Smac peptide enhances the effect of etoposide-induced apoptosis in human glioblastoma cell lines. J. Neurooncol., 2006, 77(3), 247-255

[121] Yang, L.; Mashima, T.; Sato, S.; Mochizuki, M.; Sakamoto, H.; Yamori, T.; Oh-Hara, T.; Tsuruo, T. Predominant suppression of apoptosome by inhibitor of apoptosis protein in non-small cell lung cancer H460 cells: therapeutic effect of a novel polyarginineconjugated Smac peptide. Cancer Res., 2003, 63(4), 831-837

[122] Kipp, R.A.; Case, M.A.; Wist, A.D.; Cresson, C.M.; Carrell, M.; Griner, E.; Wiita, A.; Albiniak, P.A.; Chai, J.; Shi, Y.; Semmelhack, M.F.; McLendon, G.L. Molecular targeting of inhibitor of apoptosis proteins based on small molecule mimics of natural binding partners. Biochemistry, 2002, 41(23), 7344-7349

[123] Nikolovska-Coleska, Z.; Meagher, J.L.; Jiang, S.; Kawamoto, S.A.; Gao, W.; Yi, H.; Qin, D.; Roller, P.P.; Stuckey, J.A.; Wang, S. Design and characterization of bivalent Smac-based peptides as antagonists of XIAP and development and validation of a fluorescence polarization assay for XIAP containing both BIR2 and BIR3 domains. Anal. Biochem., 2008, 374(1), 87-98

[124] Vucic, D.; Stennicke, H.R.; Pisabarro, M.T.; Salvesen, G.S.; Dixit, V.M. ML-IAP, a novel inhibitor of apoptosis that is preferentially expressed in human melanomas. Curr. Biol., 2000, 10(21), 13591366

[125] Kasof, G.M.; Gomes, B.C. Livin, a novel inhibitor of apoptosis protein family member. J. Biol. Chem., 2001, 276(5), 3238-3246

[126] Franklin, M.C.; Kadkhodayan, S.; Ackerly, H.; Alexandru, D.; Distefano, M.D.; Elliott, L.O.; Flygare, J.A.; Mausisa, G.; Okawa, D.C.; Ong, D.; Vucic, D.; Deshayes, K.; Fairbrother, W.J. Structure and function analysis of peptide antagonists of melanoma inhibitor of apoptosis (ML-IAP). Biochemistry, 2003, 42(27), 8223-8231

[127] Wheatley, S.P.; McNeish, I.A. Survivin: a protein with dual roles in mitosis and apoptosis. Int. Rev. Cytol., 2005, 247, 35-88

[128] Altieri, D.C. Survivin, cancer networks and pathway-directed drug discovery. Nat. Rev. Cancer, 2008, 8(1), 61-70

[129] Fortugno, P.; Beltrami, E.; Plescia, J.; Fontana, J.; Pradhan, D.; Marchisio, P.C.; Sessa, W.C.; Altieri, D.C. Regulation of survivin function by Hsp90. Proc. Natl. Acad. Sci. USA, 2003, 100(24), 13791-13796

[130] Plescia, J.; Salz, W.; Xia, F.; Pennati, M.; Zaffaroni, N.; Daidone, M.G.; Meli, M.; Dohi, T.; Fortugno, P.; Nefedova, Y.; Gabrilovich, D.I.; Colombo, G.; Altieri, D.C. Rational design of shepherdin, a novel anticancer agent. Cancer Cell, 2005, 7(5), 457-468

[131] Junttila, M.R.; Evan, G.I. p53 - a Jack of all trades but master of none. Nat. Rev. Cancer, 2009, 9(11), 821-829

[132] Vousden, K.H.; Lu, X. Live or let die: the cell's response to p53. Nat. Rev. Cancer, 2002, 2(8), 594-604

[133] Baker, L.; Quinlan, P.R.; Patten, N.; Ashfield, A.; Birse-StewartBell, L.J.; McCowan, C.; Bourdon, J.C.; Purdie, C.A.; Jordan, L.B.; Dewar, J.A.; Wu, L.; Thompson, A.M. p53 mutation, deprivation and poor prognosis in primary breast cancer. Br. J. Cancer, 2010, 102(4), 719-726

[134] Hupp, T.R.; Sparks, A.; Lane, D.P. Small peptides activate the latent sequence-specific DNA binding function of p53. Cell, 1995, 83(2), 237-245

[135] Selivanova, G.; Iotsova, V.; Okan, I.; Fritsche, M.; Strom, M.; Groner, B.; Grafstrom, R.C.; Wiman, K.G. Restoration of the growth suppression function of mutant $\mathrm{p} 53$ by a synthetic peptide derived from the p53 C-terminal domain. Nat. Med., 1997, 3(6), 632-638

[136] Kim, A.L.; Raffo, A.J.; Brandt-Rauf, P.W.; Pincus, M.R.; Monaco, R.; Abarzua, P.; Fine, R.L. Conformational and molecular basis for induction of apoptosis by a p53 C-terminal peptide in human cancer cells. J. Biol. Chem., 1999, 274(49), 34924-34931

[137] Snyder, E.L.; Meade, B.R.; Saenz, C.C.; Dowdy, S.F. Treatment of terminal peritoneal carcinomatosis by a transducible p53-activating peptide. PLoS Biol., 2004, 2(2), E36

[138] Snyder, E.L.; Saenz, C.C.; Denicourt, C.; Meade, B.R.; Cui, X.S.; Kaplan, I.M.; Dowdy, S.F. Enhanced targeting and killing of tumor cells expressing the CXC chemokine receptor 4 by transducible anticancer peptides. Cancer Res., 2005, 65(23), 10646-10650

[139] Zhou, N.; Luo, Z.; Luo, J.; Fan, X.; Cayabyab, M.; Hiraoka, M.; Liu, D.; Han, X.; Pesavento, J.; Dong, C.Z.; Wang, Y.; An, J.; Kaji, H.; Sodroski, J.G.; Huang, Z. Exploring the stereochemistry of 
CXCR4-peptide recognition and inhibiting HIV-1 entry with Dpeptides derived from chemokines. J. Biol. Chem., 2002, 277(20), $17476-17485$

[140] Guida, E.; Bisso, A.; Fenollar-Ferrer, C.; Napoli, M.; Anselmi, C.; Girardini, J.E.; Carloni, P.; Del Sal, G. Peptide aptamers targeting mutant p53 induce apoptosis in tumor cells. Cancer Res., 2008, 68(16), 6550-6558

[141] Hoppe-Seyler, F.; Butz, K. Peptide aptamers: powerful new tools for molecular medicine. J. Mol. Med., 2000, 78(8), 426-430

[142] Cragg, G.M. Paclitaxel (Taxol): a success story with valuable lessons for natural product drug discovery and development. Med. Res. Rev., 1998, 18(5), 315-331

[143] Chen, H.M.; Wang, W.; Smith, D.; Chan, S.C. Effects of the antibacterial peptide cecropin B and its analogs, cecropins B-1 and B2, on liposomes, bacteria, and cancer cells. Biochim. Biophys. Acta, 1997, 1336(2), 171-179

[144] Cruciani, R.A.; Barker, J.L.; Zasloff, M.; Chen, H.C.; Colamonici, O. Antibiotic magainins exert cytolytic activity against transformed cell lines through channel formation. Proc. Natl. Acad. Sci. USA, 1991, 88(9), 3792-3796

[145] Raghuraman, H.; Chattopadhyay, A. Melittin: a membrane-active peptide with diverse functions. Biosci. Rep., 2007, 27(4-5), 189223

Received: April 14, 2010

Accepted: May 30, 2010
[146] Xue, Z.; Yu, W.; Wu, M.; Wang, J. In vivo antitumor and antioxidative effects of a rapeseed meal protein hydrolysate on an S180 tumor-bearing murine model. Biosci. Biotechnol. Biochem., 2009, 73(11), 2412-2415

[147] Park, K.; Choi, K.; Kim, H.; Kim, K.; Lee, M.H.; Lee, J.H.; Kim Rim, J.C. Isoflavone-deprived soy peptide suppresses mammary tumorigenesis by inducing apoptosis. Exp. Mol. Med., 2009, 41(6), 371-381

[148] Chen, J.Y.; Lin, W.J.; Wu, J.L.; Her, G.M.; Hui, C.F. Epinecidin-1 peptide induces apoptosis which enhances antitumor effects in human leukemia U937 cells. Peptides, 2009, 30(12), 2365-2373

[149] Sato, M.; Sagawa, M.; Nakazato, T.; Ikeda, Y.; Kizaki, M. A natural peptide, dolastatin 15 , induces $\mathrm{G} 2 / \mathrm{M}$ cell cycle arrest and apoptosis of human multiple myeloma cells. Int. J. Oncol., 2007, 30(6), 1453-1459

[150] Mader, J.S.; Mookherjee, N.; Hancock, R.E.; Bleackley, R.C. The human host defense peptide LL-37 induces apoptosis in a calpainand apoptosis-inducing factor-dependent manner involving Bax activity. Mol. Cancer Res., 2009, 7(5), 689-702

[151] Wu, J.M.; Jan, P.S.; Yu, H.C.; Haung, H.Y.; Fang, H.J.; Chang, Y.I.; Cheng, J.W.; Chen, H.M. Structure and function of a custom anticancer peptide, CB1a. Peptides, 2009, 30(5), 839-848 